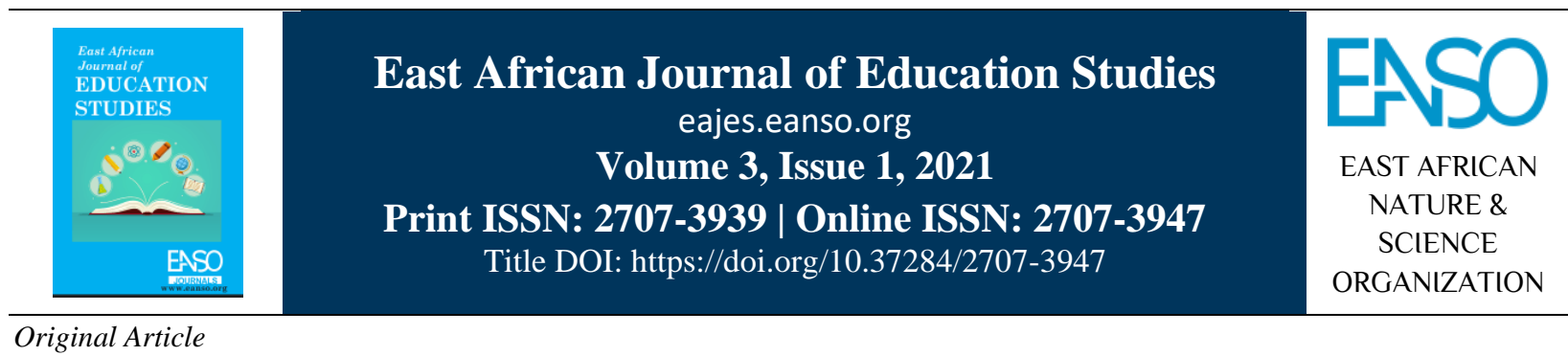

\title{
Youth Employability: Fostering University-Industry Links in Syllabus Design
}

\author{
Prof. Geoffrey Mokua Maroko, $P h D^{* 1} \&$ Dr Larry Mutinda Ndivo, PhD ${ }^{1}$ \\ 1* Department of Linguistics and Languages, Machakos University, P. O. Box 136-90100, Machakos, Kenya. \\ *Correspondence Email: gmaroko@mksu.ac.ke.
}

Article DOI: https://doi.org/10.37284/eajes.3.1.360

\section{Date Published: ABSTRACT}

13 July 2021 The potential of young people to be agents of social and economic progress continues to be undermined by massive unemployment. According to statistics

Keywords: on the Ministry of Public Service, Youth and Gender affairs website, youth

Employability Skills, unemployment in Kenya stands at $61 \%$. This is very alarming yet according to

University-Industry

Interface,

Syllabus Design,

Stakeholder

Engagement, $c$. the Global Youth Development Index and Report of 2016. Young people are a force for peace, democracy, equality and good governance, a catalyst for global consensus-building, and an essential resource for sustainable development and poverty eradication. It is interesting that among the unemployed youth are certificate, diploma and degree holders! Is there a disconnect between academic training and resultant qualifications on the one hand and youth employability on the other? Why are the youth unemployed when social media platforms, print and electronic media, and the internet are full of job advertisements day in day out? My hypothesis is that syllabi for the implementation of academic programmes in the Universities are devoid of employability skills which are a critical link in the University-Industry interface. To explore the hypothesis, this paper began by describing the $21^{\text {st }}$ Century employability skills which are selfmanagement and taking responsibility, working effectively with other people, business and customer awareness, decision-making and problem-solving, initiative and enterprise, communication and literacy, numeracy, and using ICT. Focusing on teaching in selected higher education institutions, this paper further reviews selected job advertisements to identify the salient skills that industry players seek in job applications. Next, the paper evaluates university course syllabi with the aim of establishing how these skills have been integrated. The paper recommends that University-Industry stakeholder engagement is integral to syllabus design and implementation in addition to fostering youth employability.

172 This work is licensed under a Creative Commons Attribution 4.0 International License. 
East African Journal of Education Studies, Volume 3, Issue 1, 2021

Article DOI: https://doi.org/10.37284/eajes.3.1.360

APA CITATION

Maroko, G. M., \& Ndivo, L. M. (2021). Youth Employability: Fostering University-Industry Links in Syllabus Design. East African Journal of Education Studies, 3(1), 172-184. https://doi.org/10.37284/eajes.3.1.360.

\section{CHICAGO CITATION}

Maroko, Geoffrey Mokua, and Larry Mutinda Ndivo. 2021. "Youth Employability: Fostering University-Industry Links in Syllabus Design". East African Journal of Education Studies 3 (1), 172-184. https://doi.org/10.37284/eajes.3.1. 360.

\section{HARVARD CITATION}

Maroko, G. M. and Ndivo, L. M. (2021) "Youth Employability : Fostering University-Industry Links in Syllabus Design”, East African Journal of Education Studies, 3(1), pp. 172-184. doi: 10.37284/eajes.3.1. 360.

\section{IEEE CITATION}

G. M. Maroko, and L. M. Ndivo, "Youth Employability: Fostering University-Industry Links in Syllabus Design”, EAJES, vol. 3, no. 1, pp. 172-184, Jul. 2021.

\section{MLA CITATION}

Maroko, Geoffrey Mokua, and Larry Mutinda Ndivo. "Youth Employability: Fostering University-Industry Links in Syllabus Design”. East African Journal of Education Studies, Vol. 3, no. 1, Jul. 2021, pp. 172-184, doi:10.37284/eajes.3.1.360.

\section{INTRODUCTION}

The Global Youth Development Index and Report (The Commonwealth, 2016) indicates that youth aged between 15 and 29 comprise 1.8 billion people. It is estimated that 87 per cent of them live in developing countries. In relation to the entire global population, therefore, young people make up approximately one-quarter of humanity. Ideally, young people ought to be agents of social and economic progress yet a majority are not able to land decent work opportunities. The Global Youth Development Index and Report (The Commonwealth, 2016, p .27) further reports that in every part of the world, young people are at least twice as likely as others to be unemployed. The contribution of the youth to the attainment of the UN Sustainable Development Goals is an urgent need for society today. But how are the institutions of higher learning packaging them for the changing employment landscape? Therefore, an audit of the process of graduating from education to employment and from dependent to independent living is vital. It is important to know what happens between graduation and employment or lack of it.

According to the 2014 UNDP report, the most pressing challenge for Kenya is to provide jobs for young people aged between 18 and 25 years. However, Ernest (2014) portrays the employment crisis as caused by a lack of the skill set needed for the contemporary economy. An academic certificate from a tertiary institution pays little attention to a specific skill set (African Development Bank, 2012). The Kenyan Cabinet Secretary for Education in 2018 revealed that higher education standards had fallen, with students graduating not ready to compete in the job market (Odour, 2018). The CS noted that after meeting student leaders, they informed her that they are not receiving quality education in the universities. She said the following about them:

"They personally told me that they are no longer half-baked, in fact, they are quarter-baked, and this is unacceptable."

Granted that the world is changing rapidly, and with these changes come new supply chains, new skill requirements and new opportunities. A prospective worker, therefore, needs to focus on change and should adapt to new conditions, demands and opportunities. A graduate should be able to demonstrate how knowledge and skills acquired can apply to a job they seek, what value they could bring into the organisation and prospects for growing the organisations.

This paper aims to answer the following questions:

- What are the $21^{\text {st }}$-century employability skills?

173 This work is licensed under a Creative Commons Attribution 4.0 International License. 
- How are these skills integrated into university training?

- What skills do employers seek in job applicants?

Equipping learners with employability skills is key for tackling the unemployment crisis in society and for sustainable development. The Global Youth Development Index and Report (The Commonwealth, 2016, p. 15) note that opportunities to gain employment in secure and meaningful jobs or pursue financial independence are a key feature of a well-functioning society. This can address crises that come with unemployment including homicides, drug and substance abuse, armed crime and terrorism.

\section{LITERATURE REVIEW}

According to the British Council (2016, p. 24), employability can be defined as developing the right set of skills and attributes needed for securing a job and being adaptable to the labour market.

The British Council (2016) notes that Kenya faces a growing problem of what has been referred to as the 'youth bulge', with 80 per cent of its population under 35 years old. The youth, aged 15-34 years, which form 35 per cent of the population have the highest unemployment rate of 67 per cent. Many of those who fail to secure jobs are university graduates. This is so despite the fact that the higher education system consists of public and private universities, a number of middle level technical and vocational institutions that are often linked to universities, and research centres such as the Kenya
Agricultural Research Institute (KARI), the Kenya Medical Research Institute (KEMRI), International Centre for Insect Physiology and Ecology (ICIPE) and the International Livestock Research Institute (ILRI).

Various government policy documents: for example, the country's long-term development blueprint: Vision 2030, the first Medium Term Plan (2008-2012), and the Labour, Youth and Human Resource Development Sector Plan (2008-2012) tried to deal with this problem. According to these documents, the country's employment problem was manifest in the slow growth of formal sector employment vis-à-vis a burgeoning informal sector that offers a large and increasing number of unsustainable jobs (British Council, 2016).

Another study by the Inter-University Council of East Africa (IUCEA, 2014) asserts that as many as 49 per cent of new graduates from Kenyan universities are not adequately prepared for the labour market. Part of the unpreparedness is probably attributed to a lack of limited exposure to the industry through internship programmes. Other possibilities point towards lack or poorly developed employability skills, also referred to as $21^{\text {st }}$ Century skills.

The British Council (2016, p. 25) points out that knowledge and critical thinking are the core skills demanded by employers and therefore important graduate attributes needed to gain employment and be successful in the workplace. Table 1 shows the skills landscape from 2015 to 2020.

Table 1: Demand for skills in different industry sectors

\begin{tabular}{lll}
\hline Skill & $\mathbf{2 0 1 5}$ & $\mathbf{2 0 2 0}$ \\
\hline Complex problem-solving & 36 & 36 \\
Social skills/collaboration & 20 & 19 \\
Initiative and enterprise & 16 & 17 \\
Business and customer awareness & 14 & 13 \\
ICT/Technical skills & 14 & 12 \\
Creativity and innovation & 11 & 15 \\
Communication skills & 10 & 10 \\
\hline
\end{tabular}

174 | This work is licensed under a Creative Commons Attribution 4.0 International License. 


\begin{tabular}{lll}
\hline Skill & $\mathbf{2 0 1 5}$ & $\mathbf{2 0 2 0}$ \\
\hline Physical abilities & 5 & 4 \\
\hline
\end{tabular}

Table 1 indicates that the future of jobs will be highly pegged on complex problem-solving skills, social skills, initiative and enterprise, business and customer awareness, technical skills, creativity and innovation and communication skills. This calls for concerted efforts by stakeholders such as curriculum developers, the Ministry of Education, the Commission for Higher Education, the universities and others to develop mechanisms for anchoring and mainstreaming these skills in training institutions. It is notable that the demand for graduates with creativity and innovation will rise from 11 per cent in 2015 to 15 per cent in 2010 . University-industry links must be created and strengthened to give learners a head start in the world of work.

It is the responsibility of all stakeholders to unpack the factors influencing youth employability. The British Council (2016) reports that a student's background is considered to significantly determine youth employability. Firstly, it is said to largely determine if students will be able to go to their university of choice and study a programme of their choice, or if they will be forced to go to another university and even study a programme they would not otherwise have chosen, simply in order to go to university and gain a degree to improve their job prospects. Another factor affecting youth employability is social capital which relates to networks of family and friends that the student develops in the hope that they will connect him to a job. According to the report, employability can also be a function of career aspirations where most youths prefer to work in the public sector as opposed to the private sector. The argument is that privatesector jobs are unstable. It then means that if all graduates want to secure jobs in the public sector, the number of places will not be enough for all of them. The reputation of a university and its international standing in addition to whether it is situated in an urban or rural setting also influences employability. The report (The British Council, 2016 , p. 29) cites the field of study as another determinant of employment with Science, Engineering and Technology fields having better prospects than humanities and social sciences.

\section{RESEARCH DESIGN AND METHODOLOGY}

This research report adopted a qualitative design. First, a critical reading of literature comprising policy documents such as Vision 2030, Second Medium-term Plan, published research reports, World Bank reports and the newspapers were carried out. The purpose of the review was to identify the employability skills and this activity yielded six $21^{\text {st }}$ Century skills which currently count as employability skills. This process was also deemed to uncover how the six skills are integrated into the process chain of student development.

The next activities involved a study of job advertisements and published interview of chief executive officers of premier organisations. These were drawn from the Kenyan Daily Nation newspaper on selected Fridays. The Daily Nation was selected because it has the widest readership of all the newspapers in Kenya. The choice of Fridays was purposeful. This is the day known for many job advertisements.

Syllabi from Five Kenyan Universities were also reviewed following the content analysis method. The purpose of this review was to ascertain the extent to which employability skills were integrated, if at all. To corroborate the results of the assessment of syllabi, further critical literature reviews were carried out which facilitated the discussion of the results of the study.

175 This work is licensed under a Creative Commons Attribution 4.0 International License. 


\section{RESULTS AND DISCUSSION}

\section{Employability Skills}

The different viewpoints in terms of the nuances of what employers want from employees in the $21^{\text {st }}$ Century have led to a number of employability skills. According to Fadel (2008), these are discussed as follows:

\section{Self-Management and Taking Responsibility}

Self-management behaviour is expressed through individual actions enabling one to pursue a goal. In addition, it incorporates time management and initiative to achieve the best results. Another demonstration of the skill is the ability to use feedback to improve the quality of a service or product. On the other hand, taking responsibility means that one is able to set goals and then prioritise actions to achieve those goals. An individual is accountable for the actions of the group as well as their own actions.

Ways in which this skill can be put into effect in students include taking the opportunity to find out about something for oneself, taking the lead in an activity, making a planner remember school assignments, showing readiness to learn, making own choices to take responsibility for one's health, taking over a household or other shared family responsibilities, and making the arrangements for team or club arrangements.

\section{Working Effectively with Other People}

This skill entails respecting others, co-operating, negotiating/persuading, contributing to discussions, and awareness of interdependence with others. This means an individual should understand the dynamics of a group and can work with the group. A person should respect the group members and be responsive and open to their thoughts and opinions, and value their contributions. People contribute to discussions in a constructive and considerate manner. They are able to negotiate conflict situations, be able to share information and be aware of the interdependence of group members. In the world of work, this skill ensures different people can bring their synergies for the solution of complex and intricate problems.

Learning activities that can bring this to effect include working on a group project with others. helping others with their work, encouraging others when situations become difficult, participating in actual work experience where one is part of a work team, participating in a club or sports team, and being sensitive to the different cultural traditions of other groups of people.

\section{Business and Customer Awareness}

The skill entails an understanding of the drivers for business success - including the importance of innovation, taking calculated risks, the need to provide customer satisfaction and building customer loyalty. This means a person understands what makes a business successful and can communicate with customers by responding effectively to their queries, complaints and requests. It also means that one can build customer loyalty and customer satisfaction through one's relationship and level of service to them.

A training programme can inculcate this skill in learners by linking them to industry for internships, encouraging them to engage in out out-of-school jobs or helping with a family business, doing readings on economic and political issues, and doing voluntary work.

\section{Decision-making and Problem-solving}

Problem-solving entails analysing facts and situations and consequently applying creative thinking to develop appropriate solutions. One should be able to assess a situation and identify if there are problems. It involves a demonstration of an ability to discuss the problems and obtain different opinions, and evaluation of the facts and different options and eventual implementation of a 
creative, practical or innovative solution. Problemsolving also means ensuring that the solution or decision taken works.

Learning activities can include working in a group or as an individual to achieve a solution to a problem, fixing a problem that has occurred, finding something which has gone missing, improving the design of something, looking for an internship placement, suggesting a different approach to an issue etc.

\section{Initiative and Enterprise}

Broadly, these skills entail an ability to demonstrate an innovative approach, creativity, collaboration and risk-taking. An individual is able to see innovative ways of doing things, acting on opportunities and taking the initiative. When working for an employer, it means looking at a situation from a different angle or perspective. It might mean having the confidence to propose a new idea that might streamline or improve a process already in place.

Training students on these attributes will involve encouraging them to set up a group project, a new club or a team. They can also be trained on how to respond to an emergency, how to find a solution for an unexpected difficulty, how to sell things at during a conference, making jewellery to sell to friends etc.

\section{Communication and Literacy}

This attribute focuses on the application of literacy and also the ability to produce clear, structured written work and oral literacy - including listening and questioning. Apart from being a good listener, one can express themselves clearly when talking or in writing. They are able to explain things to people from diverse backgrounds. They can also read and understand what they read, including charts, graphs and diagrams.
Activities to develop this attribute in learners will include writing for a newspaper or magazine, taking part in a debate and writing a blog. Learners can be encouraged to enter writing competitions or participate in interactive talk shows on radio and TV.

\section{Numeracy}

This skill focuses on general mathematical awareness and its application in practical contexts and also being able to manage mathematical problems in everyday life and in the workplace. It means that an individual can decide what should be calculated or measured and use the correct tools and methods to record relevant data. They are able to verify calculations and make estimates. Activities to develop this attribute will entail working towards Math or Numeracy qualifications at college, handling cash transactions during an internship, managing the budget for a project or club, weighing and measuring ingredients etc.

\section{Using ICT}

This attribute entails the application of information technology basic IT skills, including familiarity with word processing, spreadsheets, file management and the use of internet search engines. It means that the individual has a range of IT skills and can apply the correct technology to a situation or problem. They are also continuously learning about new products and ways to use them. Building this attribute will involve working towards an ICT qualification at college, creating computer or phone apps, presenting information in spreadsheets, using computer graphics, becoming skilled at online games and searching for relevant information online.

\section{Key Skills in Selected Job Adverts}

Adverts were selected from the Daily Nation to establish the key attributes employers expect in job applicants. Table 2, therefore, presents a summary of four adverts as illustrated below:

177| This work is licensed under a Creative Commons Attribution 4.0 International License. 
East African Journal of Education Studies, Volume 3, Issue 1, 2021

Article DOI: https://doi.org/10.37284/eajes.3.1.360

Table 2: Attributes in selected job advertisements

\begin{tabular}{|c|c|c|c|c|}
\hline Organisation & Date & Job & $\begin{array}{l}\text { Academic } \\
\text { qualification }\end{array}$ & Attributes \\
\hline $\begin{array}{l}\text { Emergency Aid } \\
\text { Somalia (DKH-SOM) }\end{array}$ & $\begin{array}{l}\text { Friday, } \\
\text { July 21, } \\
2017\end{array}$ & $\begin{array}{l}\text { Projects } \\
\text { Officer }\end{array}$ & $\begin{array}{l}\text { Bachelor's } \\
\text { degree }\end{array}$ & $\begin{array}{l}\text { a. Fluency in spoken and written } \\
\text { business English } \\
\text { b. Good analytical and critical } \\
\text { thinking skills } \\
\text { c. A background in accounting }\end{array}$ \\
\hline $\begin{array}{l}\text { GEMS Cambridge } \\
\text { International School }\end{array}$ & $\begin{array}{l}\text { Friday, } \\
\text { September } \\
1,2017\end{array}$ & $\begin{array}{l}\text { Performing } \\
\text { Arts } \\
\text { Technician }\end{array}$ & Diploma & $\begin{array}{l}\text { a. Willingness to develop and } \\
\text { learn new skills } \\
\text { b. Team player } \\
\text { c. Experience with technical, } \\
\text { sound, lighting and filming } \\
\text { equipment }\end{array}$ \\
\hline $\begin{array}{l}\text { Mombasa-based } \\
\text { company }\end{array}$ & $\begin{array}{l}\text { Friday, } \\
\text { April 27, } \\
2017\end{array}$ & $\begin{array}{l}\text { Management } \\
\text { trainee }\end{array}$ & $\begin{array}{l}\text { Bachelor's in } \\
\text { Business }\end{array}$ & $\begin{array}{l}\text { a. Excellent communication } \\
\text { skills } \\
\text { b. Coordination and client } \\
\text { support services } \\
\text { c. Good interpersonal skills } \\
\text { d. Knowledge of computer } \\
\text { systems and applications }\end{array}$ \\
\hline World Bank Group & $\begin{array}{l}\text { Friday, } \\
\text { April 27, } \\
2018\end{array}$ & $\begin{array}{l}\text { Office } \\
\text { Assistant }\end{array}$ & $\begin{array}{l}\text { Bachelor's } \\
\text { Degree }\end{array}$ & $\begin{array}{l}\text { a. Ability to communicate } \\
\text { effectively in writing and } \\
\text { orally in English }\end{array}$ \\
\hline
\end{tabular}

Table 2 indicates that academic qualifications alone cannot land someone a job. A host of other attributes are needed. These skills include communication efficiency, collaboration, critical and problemsolving skills, ICT and numeracy skills. The skills are expected to prepare applicants to take on new challenges in the workplace some of which never existed before. In jobs such as Management Trainee, it is also notable that applicants can join as a general employee but can only later specialise after receiving exposure to the various opportunities in the organisation.

The attributes in Table 2 can be aligned to the relevant $21^{\text {st }}$ Century Skills. This information is summarised in Table 3.

Table 3: Alignment of attributes to 21st Century Skills

\begin{tabular}{llll}
\hline Attribute & $\mathbf{2 1}^{\text {st }}$ Century Skill \\
\hline 1 & Good analytical and critical thinking skills & Critical thinking/problem solving \\
Peam player & Partnership/teamwork/collaboration \\
& & \\
& Coordination and client support services & & \\
& Good interpersonal skills & Creativity and innovation & \\
3 & Good analytical and critical thinking skills & The initiative, lifelong learning and \\
4 & A background in accounting & enterprise & Information, Communication and \\
& Willingness to develop and learn new skills & Technology & \\
5 & Knowledge of computer systems and applications & & \\
&
\end{tabular}

178 This work is licensed under a Creative Commons Attribution 4.0 International License. 


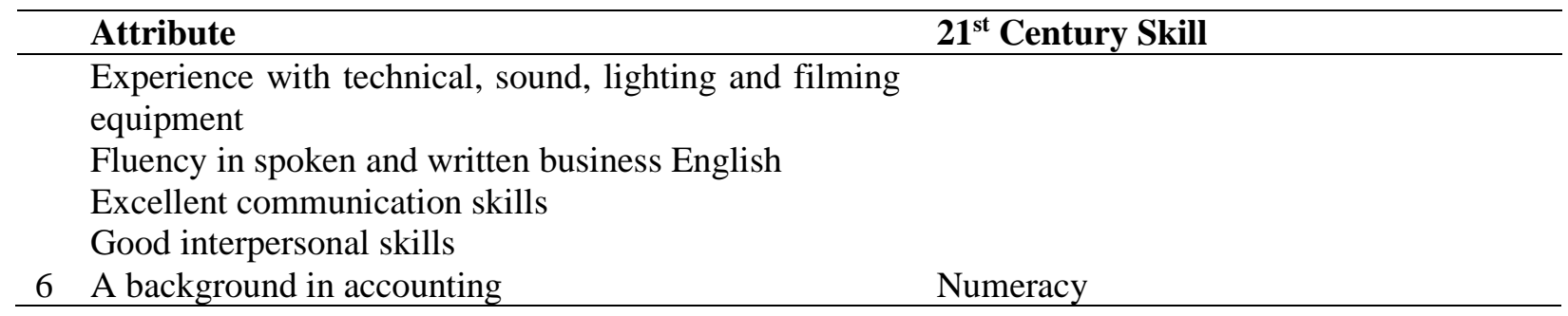

Table 3 indicates that job applicants must of necessity possess such $21^{\text {st }}$ Century Skills as critical thinking/problem-solving; creativity and innovation; initiative lifelong learning and enterprise; information, communication and technology; and numeracy.

A study of interviews recorded in the daily newspapers present views that corroborate the information in Table 2 and Table 3. For instance, Kahongeh (2018, p. 6) summarises all these attributes in the following assertion:

If you are not proactive, today's job market has no place for you. Employers are looking for individuals who take the initiative, think on their feet, are open to learning, and who challenge them with out-of-the-box ideas.

Other illustrations can be drawn from the Daily Nation of Friday, March 23, 2018. In an interview with Chief Executive Officers of four premier companies (the East African Breweries Limited, Safaricom, Kenya Red Cross, and the Daily Nation), there seems to be unanimity as to the centrality of $21^{\text {st }}$ skills in graduate employability.

The Chief Executive Officer of the East African Breweries Limited said the following:

Through our Diageo's Global graduate Programme, we tap into the talent of young people with the ability to learn and adapt fast to deliver against the tide. We search for unique behavioural traits such as relentlessness and agility, entrepreneurial ability and boldness in the execution of ideas, aspirational and purposedriven self-starters.
Asked about how young people who wish to work for the East African Breweries should package themselves, he added:

You must think 'outside the bottle' and be ready to constantly reinvent yourself to stay relevant and in pace with the volatile, uncertain, complex and ambiguous (VUCA) landscape in which we operate. We engage young people who are stimulated to join us, are proud of what we stand for, moved by our vision and are motivated to stay with us to position our brand more effectively across the market.

These assertions underscore the fact that employability skills are as important as the basic academic qualification requirements, meaning that without the skills, one cannot be employable despite excellent academic qualifications. Similar sentiments were made by the CEO of the telecommunication company, Safaricom. The respondent observed as follows:

We look for bright, passionate, well-rounded individuals who have the potential to grow into business leaders. The individuals must demonstrate personal drive, applied thinking, be change agents and have the ability to engage wider groups of people at all levels of our organisation hierarchy.

On common mistakes applicants make, the respondent noted that:
Most young job seekers submit hurriedly assembled application documents instead of a well-detailed resume and cover letter with accurate information. Candidates should therefore prepare a neat resume that reflects their qualifications and work experience.

179| This work is licensed under a Creative Commons Attribution 4.0 International License. 
It is clear that employability skills such as critical thinking and problem-solving skills, innovation and creative thinking, initiative and taking responsibility are very critical determinants of employment. The CEO notes that the problem is compounded by the poor functional writing skills where applicants are unable to write resumes and cover letters which bring out these critical skills.

Innovative and creative thinking, collaborative and interpersonal skills are at the core of hiring decisions at the Kenya Red Cross. Asked about the attributes Red Cross considers, the CEO noted:

The individuals are expected to exercise their unique skills to drive positive change in their communities, a platform that also provides peer to peer learning among themselves. The flexibility of youth volunteers ensures that emergencies are responded to promptly and effectively. The programme has also inculcated the attribute of empathy in the youth and the best practices in humanitarian action.

Versatility, initiative and enterprise In the Daily Nation, the respondent noted:

For a media landscape where grounds are constantly shifting, we go for someone who is change-oriented. Media lifespan, especially TV, is very short. We, therefore, evaluate the candidates' ability to work on the digital, broadcast, and print versions of our media; being multi-dimensional betters their chance of flourishing.

\section{Status of Implementation of Employability Skills in the Universities}

This section is divided into two parts, namely: Curriculum design and delivery and the status of University-Industry links. Information for the sections was gathered from policy documents, interviews of university lecturers, content analysis of media information and researcher experience and observations. The two parts are illustrated as follows:

\section{Curriculum Design and Delivery}

- The syllabus design template by the Commission of University Education is silent on the $21^{\text {st }}$ Century and employability skills. In most universities, the template offered by CUE is rarely followed, leaving lecturers to construct one-to-two-page course outlines without such key elements as learning outcomes, teaching/learning activities, and assessment opportunities.

- Apart from Bachelor of Education students, students in all other academic programmes rarely, if at all, go for an internship during their studies in order to acquire much needed prior exposure to the world of work. While there are Teaching Practice coordinators in the sampled institutions, there are no corresponding industrial attachment coordinators to facilitate placement of non-education students to organisations for attachment. While it is commendable that Education students are allowed to go for teaching practice, it emerged that they are assessed once by their institutions to cut down on costs. Some universities have relinquished their assessment role to the heads of the institutions where the students are attached.

- The most notable Common Unit in the selected universities was communication skills. This was mainly offered once in the first semester of the first year understandably to help learners to cope with University-level learning. The course features listening skills, speaking skills, reading skills, writing skills, library skills, and study skills. The content in the course is too wide to be covered in a 14-week semester. As a result, the course is mainly theoretical and does not give learners an opportunity to grow their skills through practice.

180| This work is licensed under a Creative Commons Attribution 4.0 International License. 
- Few Universities including Kenyatta and Strathmore have established functional innovation and incubation hubs. Even those that have established the centres are ill-equipped with requisite resources including experienced mentors to guide students to develop their ideas into prototypes. As a result, few students are able to use the facilities meaning that developing critical, creative and problem-solving skills in college students still remains a tall order.

It is clear from these findings that universities are not doing enough in terms of curriculum design and delivery to integrate and mainstream the $21^{\text {st }}$ Century skills. Without this arrangement, it is difficult for learners to acquire these skills. The next part presents observations about the UniversityIndustry links.

\section{University-Industry Links}

Results of this investigation reveal a weak link between universities and industry. The following are the specific findings:

- Universities are yet to establish functional placement offices to link students with industry. Even those that have established the office have not hired people with the right credentials to run the office. It is worrying that the office is not facilitated with basic infrastructures such as adequate computers and communication equipment.

- Few universities have signed memoranda of understanding with industry to open doors for internship for their students. Even those that have signed such memoranda, it benefits a few students, especially those pursuing STEM disciplines as opposed to those studying the humanities, arts and social sciences.

- There was little evidence for the organisation of career days or fairs to expose students to jobs available in the labour market and the requirements for accessing the jobs. This leaves the students to join the labour market with a scanty understanding of what is required.

- There was no evidence of tracer studies to establish where alumni end up in the labour market and how they are doing. Such tracer studies can give indicates on areas to focus on when revising curricula.

- Industry players are expected to be key stakeholders during academic programme development and implementation. However, it emerged that universities develop curricula without engagement with industry. The process is nothing more than duplicating programmes already being offered in other universities instead of universities establishing themselves as centres of excellence in unique programmes.

\section{DISCUSSION}

From the lack of employability skills in those seeking employment in various organisations, it is clear that youths are not adequately prepared for the world of work. The youths will continue to complain of lack of jobs, yet organisations are ever advertising vacancies. Some explanations can be found in the literature. According to Omolo (2010, p. 14), the causes of Kenya's unemployment can be linked to inadequate training and consequent lack of skills. Similar sentiments can be found in Government documents. For example, a Kenyan Government policy document, the Sector Plan for Labour, Youth and Human Resource Development Sector (2008-2012), contends that unemployment in Kenya is mainly attributed to mismatch in skills development and demand, imperfect information flow and inherent rigidities within the country's labour market. This trend calls for deliberate interventions from universities, industry and the private sector to come up with mechanisms for the development of these skills in the youth.

However, the meaning of employability skills incorporates other dimensions. According to the

181 This work is licensed under a Creative Commons Attribution 4.0 International License. 
British Council (2016, p.50), employers in the education sector ranked most highly the quality of employability provided by an institution (52 per cent); followed by institutional reputation, relevant disciplinary knowledge, quality of discipline knowledge and successful past experience of recruiting from the institution, all ranked at the same level. On the other hand, the financial institutions ranked institutional reputation, relevant disciplinary knowledge and perception that an institution produces high-quality graduates as the foremost institutional characteristics they considered;

To stem the rising unemployment affecting the youth in the society, initiatives for skills development should be broad-based. The graduates must also demonstrate enthusiasm and a positive attitude towards the acquisition of these skills. This intervention would reverse the constant complaint from employers regarding the quality of graduates in Kenya where they are more dissatisfied with failure by the graduates to manifest a wide range of skills besides demonstrating a masterly knowledge of subject content (P.51)

\section{CONCLUSION}

From the findings and emerging discussion, it can be summarised as follows:

- The world of jobs is highly complex and everchanging. As a result, the jobs of the future do not exist today. This calls for highly skilled people who are flexible and malleable enough to adjust to the emerging job offerings.

- Institutions of higher learning are sleeping through the job landscape revolution. They seem to continue teaching the skills they taught decades ago some of which are not relevant to the workplace today.

- Universities and industry are working at crosspurposes. Each side is pushing their agenda without regard to the other when indeed they should work together for mutual interest and benefit.

\section{RECOMMENDATIONS}

Based on the conclusions of this study, a raft of recommendations can be made. These are summarised as follows:

- Integrating employability skills in the curriculum, i.e., in the course syllabus, in materials used in class, in the selection and/or preparation of classroom tasks, in examinations etc. Employers need to be engaged as key stakeholders in curriculum review processes.

- University-Industry links should be fostered to make it possible for all students in institutions of higher learning to have an internship experience. The starting point should entail scoping all organisations and conducting a skills audit to establish the skills needed per organisation. This should help in connecting students to relevant organisations for internship. As a result, they will be able to acquire practical experience in addition to theoretical knowledge from the classroom.

- Encouraging students to join and participate in clubs and societies can help them to build their employability skills. These clubs and societies include St John's Club, Debating, Scouts, Christian Union etc.

- Establishing and/or equipping career service offices with adequate personnel who can organise career talks and fairs for students on employability. The services can also extend to linking students to the industry for internship and volunteer services.

- Introduction of common courses for college students such as inter-cultural communication, citizenship, critical and creative thinking, functional writing and entrepreneurship.

182 This work is licensed under a Creative Commons Attribution 4.0 International License. 
- Establishment of incubation hubs such as the Chandaria Business Innovation and Incubation Centre (BIIC) at Kenyatta University and the Strathmore University Incubation Hub. These hubs will greatly increase the students' skill base, open new opportunities, develop business ideas and find suitable routes to a fulfilling and exciting professional development pathway.

\section{REFERENCES}

Aapola, S. (2002). Exploring Dimensions of Age in Young People's Lives: A Discourse Analytical Approach. Time \& Society 11: 295-314.

African Development Bank. (2012). African Economic Outlook 2012: Promoting Youth Employment. African Development Bank, Organisation for Economic Co-operation and Development, United Nations Development Programme \& United Nations Economic Commission for Africa.

Odour, A. (2018, April 27). Universities are in a mess, says Education CS Amina. The Standard Media, https://www.standardmedia.co.ke/educa tion/article/2001278360/amina-universities-arein-a-mess

Angel, W. A. (2015). The International Law of Youth Rights. Leiden: Koninklijke Brill.

Arnett, J.J. (2004). Emerging Adulthood: The Winding Road through the Late Teens to the Twenties. New York: Oxford University Press.

Arnett, J., Kloep, M., Hendry, L. and Tanner, J. (2011). Debating Emerging Adulthood: Stage or Process? New York: Oxford Press.

British Council (2016). Universities employability and inclusive development. Repositioning higher education in Ghana, Kenya, Nigeria and South Africa. British Council.
Cooper, T. (2012). Models of Youth Work: a Framework for Positive Skeptical Reflection. Youth \& Policy 109.

Daily Nation (Friday, July 21, 2017). Daily Nation. Nairobi: Nation Media Group Limited.

Daily Nation (Friday, September 1, 2017). Daily Nation. Nairobi: Nation Media Group Limited.

Daily Nation (Friday, April 27, 2018). Daily Nation. Nairobi: Nation Media Group Limited.

Ernest, S. (2014, June 12). Over 50 per cent of EA graduates half-baked. The East African, https://www.theeastafrican.co.ke/tea/news/eastafrica/over-50-per-cent-of-ea-graduates-halfbaked-1325280.

European Group for Integrated Social Research (2010). Misleading Trajectories: Transition Dilemmas of Young Adults in Europe. Journal of Youth Studies 4(1): 101-119.

Fadel, C. (2008). 21 ${ }^{\text {st }}$ Skills: How can you prepare students for the new global economy? Paris: OECD/CERI.

ILO. (2015a). Global Employment Trends for Youth 2015: Scaling Up Investments in Decent Jobs for Youth. Geneva: International Labour Organization.

ILO. (2015b). Towards Solutions for Youth Employment: A 2015 Baseline Report. Geneva: International Labour Organization.

Inter-University Council for East Africa (IUCEA). (2014). Regional higher education qualifications gaps. Kampala

Jones, G. (2002). The Youth Divide: Diverging Paths to Adulthood. Available online at www.ilo.org/employment/areas/youthemploym ent/WCMS_413826/lang--en/index.htm, 2018. York: York Publishing Services.

183 This work is licensed under a Creative Commons Attribution 4.0 International License. 
Kahongeh, J. (2018). These are the qualities that employers are looking for. My Network. In Daily Nation, Friday, March 23, 2018.

Omolo, J. (2010). The dynamics and trends of employment in Kenya. Nairobi: Institute of Economic Affairs

Republic of Kenya (2007). Vision 2030 Strategy for National Transformation: Accelerating Equitable Economic and Social Development for a Prosperous Kenya. Ministry of State for Planning, National Development, Nairobi.

Republic of Kenya (2008a). Sector Plan for Labour, Youth and Human Resource Development, 20082012. Ministry of Labour, Nairobi

Republic of Kenya (2008b). The National Strategy for University Education, 2007-2015. Nairobi. Ministry of Higher Education, Science and Technology

The Commonwealth. (2016). Global Youth Development Index and Report. London: Marlborough House.

UNDP. (2014). UNDP Youth Strategy 2014-2017. UN Development Agency. Retrieved on April 15, 2018, from www.undp.org/content/dam/und p/library/Democratic\%20Governance/Youth/U NDP_Youth-Strategy-2014-17_Web.pdf.

UNDP. (2015). About Human Development. UN Development Agency. Retrieved on April 15, 2018, from http://hdr.undp.org/en/humandev.

World Bank. 2013. World Development Report 2013: Jobs. World Bank.

184| This work is licensed under a Creative Commons Attribution 4.0 International License. 